2 AIMS (Anistreplase intervention Mortality Study) Trial Study Group. Effects of intravenous APSAC on mortality after acute myocardial infarction: preliminary report of a placebo controlled clinical trial. Lancet 1988;i:545-9.9.

3 ISIS-2 (Second International Study of Infarct Survival) Collaborarive Group. Randomised trial of intravenous streptokinase, oral aspirin, both, or neither Ranng 17,187 cases of suspected acute myocardial infarction: ISIS- 2 . Lamce among 17,187 cas 188 :ii:349-60.

4 Simoons ML, Serruys PW, van der Brand $M$, et al. Improved survival after early thrombolysis in acute myocardial infarction: a randomised trial by the Interuniversity Cardiology Institute in The Netherlands. Lancet 1985; ;i: Interuniver.

5 Van de Werf F, Arnold AER. Intravenous tissue plasminogen activator and size of infarct, left ventricular function, and survival in acute myocardial infarction. BMF 1988;297:1374-9.

6 TIMI Study Group. Comparison of invasive and conservative strategies after treatment with intravenous tissue plasminogen activator in acute myocardial infarction. Results of the thrombolysis in myocardial infarction (TIMI) phase II trial. $N$ Engl F Med 1989;320:618-27.

7 Papapietro SE, MacLean WA, Stanley AW, et al. Percutaneous transluminal coronary angioplasty after intracoronary streptokinase in evolving acute myocardial infarction. Am f Cardiol 1985;55:48-53.

8 Erbel R, Pop T, Henrichs K-J, et al. Percutaneous transluminal coronary angioplasty after thrombolytic therapy; a prospective controlled randomised trial. I Am Coll Cardiol 1986:8:485-95.

9 Simoons ML, Arnold AER, Betriu A, et al. Thrombolysis with tissue plasminogen activator in acute myocardial infarction: no additional benefit from immediate percutaneous coronary angioplasty. Lancet 1988;i:197-203. 10 TIMI (Thrombolysis in Myocardial Infarction) Research Group. Immediate v delayed catheterization and angioplasty following thrombolytic therapy for acute mycardiation and angioplasty following thrombolytic therapy for

1 Topol EJ Califf RM George BS, et al A randomized trial of immediate vers delaj, Calfine delayed elective angioplasty after intravenous tissue plasminogen a

12 Perry RA, Seth A, Hunt A, Shiu MF. Coronary angioplasty in unstable angina and stable angina: a comparison of success and complications. Br Hearl $\mathcal{F}$

13 Duber C, Jungluth A, Rumpelt HJ, et al. Morphology of the coronary arteries after combined thrombolysis and percutaneous transluminal coronary angioplasty for acute myocardial infarction. Am $\mathcal{F}$ Cardiol 1986;58:698-703. 14 Theroux P, Ouimet H, McCans J, et al. Aspirin, heparin or both to treat acute unstable angina. $N$ Engl I Med 1988;319:1105-11.

15 Wilcox RG, von der Lippe G, Olsson CG, et al. Trial of tissue plasminogen activator for mortality reduction in acute myocardial infarction: AngloScandinavian study of early thrombolysis (ASSET). Lancet 1988;ii:525-30.

16 Harrison DG, Ferguson DW, Collins SM, et al. Rethrombosis after reperfusion with streptokinase: importance of geometry of residual lesions. Circulation 1984;69:991-9.

17 Topol EJ, Burek K, O'Neill WW, et al. A randomized controlled trial of hospital discharge three days after myocardial infarction in the era of reperfusion. N Engl f Med 1988;318:1083-8.

(Accepted 19 December 1990)

\title{
Ethnic differences in mortality from ischaemic heart disease and cerebrovascular disease in England and Wales
}

\author{
R Balarajan
}

\begin{abstract}
Objective-To examine mortality from ischaemic heart disease and cerebrovascular disease in England and Wales by country of birth of the deceased.

Design-Standardised mortality ratios were computed by country of birth groups for ischaemic heart disease and cerebrovascular disease for 1979-83 and 1970-2 by using the five year age-sex specific rates for England and Wales for $1979-83$ as standard:
\end{abstract}

Setting-England and Wales 1970-2 and 1979-83.

Results-In 1979-83 mortality from ischaemic heart disease was highest in men and women born in the Indian subcontinent (standardised mortality ratio 136 and 146 respectively). Young Indian men suffered the greatest excess (313 at ages 20-29). Other groups with raised mortality included Irish, Scottish, and Polish born immigrants. Those born in the Caribbean, the old Commonwealth, west Europe, and the United States had low death rates. In England and Wales mortality from ischaemic heart disease declined by $5 \%$ in men and $1 \%$ in women between $1970-2$ and $1979-83$, with greatest percentage declines in immigrants born in the United States, South Africa, the old Commonwealth, the Caribbean, and France. Immigrant groups with raised mortality in the earlier period showed little improvement, and mortality from ischaemic heart disease increased among Indians ( $6 \%$ in men and $13 \%$ in women).

In 1979-83 mortality from cerebrovascular disease was highest in Caribbeans (standardised mortality ratios 176 in men and 210 in women), followed by Africans, Indians, and Irish. Rates were low in west Europeans. Mortality from stroke declined by $28 \%$ overall in this period, a rate of decline shared by most groups. Men from the Indian subcontinent showed a decline of only $3 \%$.

Conclusion-In the 1980s mortality from ischaemic heart disease and cerebrovascular disease differed significantly between ethnic groups in England and Wales. In general, ethnic groups that experienced lower mortality from ischaemic heart disease in the 1970s showed the greatest improvement over the following decade.

\section{Introduction}

Mortality attributable to circulatory diseases is known to vary between ethnic groups. In particular, a considerable excess of ischaemic heart disease among people of Indian extraction has been reported from several countries across the world. ' Another consistent finding reported from Britain and elsewhere is the high incidence of hypertension among people of AfroCaribbean descent. ${ }^{23}$

An analysis of cardiovascular mortality among immigrants in England and Wales was first published in 1984, based on national data from the 1971 census. ${ }^{4}$ A further study examined the patterns of mortality among regional and religious groups originating from the Indian subcontinent, based on deaths in England and Wales during 1975-7.

The findings presented here relate to mortality from ischaemic heart disease and cerebrovascular disease among immigrants in England and Wales during 1979-83, the latest years for which such national data are available. Comparisons are also made with mortality rates that prevailed in these groups in the preceding decade.

\section{Methods}

Mortality data for England and Wales for 1970-2 and 1979-83, classified by country of birth and centring on the 1971 and 1981 censuses respectively, were used for this analysis. Deaths were related to the corresponding populations as enumerated in the respective censuses.

Trends between 1970-2 and 1979-83 in mortality at ages 20-69 from ischaemic heart disease and cerebrovascular disease were examined for the different country of birth groups by calculating standardised mortality ratios for the two periods. The rates specific for age (five year age groups) and sex for ischaemic heart disease and cerebrovascular disease for England and Wales for 1979-83 were used as the standard in calculating the standardised mortality ratios for both periods to compare the changes across time and the country of birth groups. The percentage changes in the standardised mortality ratios for the two periods were tested for significance at the 5\% level and $95 \%$ confidence intervals given for the 1979-83 standardised mortality ratios. Age specific ratios and standardised
University of Surrey,

R Balarajan, FFCM, professor

BMF 1991;302:560-4 
mortality ratios for ages $20-49$ were also examined for $1979-83$ to give a measure of premature deaths attributed to these diseases.

For convenience, the country of birth groups are referred to as the "ethnic" groups originating in the home country. Available evidence suggests discrepancies in the recording of the individual countries of the Indian subcontinent at the census and at the time of death registration; hence the findings presented here are for the Indian subcontinent as a whole. Immigrants born in the Indian subcontinent countries of India, Pakistan, Bangladesh, and Sri Lanka are referred to as Indians in the text. Similarly, immigrants from the African and Caribbean Commonwealths are referred to as Africans and Caribbeans respectively. In the tables French, German, and Italian born immigrants have been aggregated as west Europeans, and those born in Poland and Russia as east Europeans, although these groups were also examined individually and are discussed separately where appropriate. Similarly, immigrants from Australia, Canada, and New Zealand have been aggregated as old Commonwealth.

\section{Results}

Cardiovascular disease was responsible for 283498 deaths in men and 127730 deaths in women aged 20-69 in England and Wales during 1979-83. At these ages it accounted for $49 \%$ of deaths among men in England and Wales and for $59 \%$ of deaths among men from the Indian subcontinent. In women the proportionate contribution of cardiovascular disease was $37 \%$ of overall mortality in England and Wales, $42 \%$ in women from the Indian subcontinent, and $25 \%$ in women from France and the United States.

\section{ISCHAEMIC HEART DISEASE}

Patterns in 1979-83-Ischaemic heart disease forms the largest component of cardiovascular mortality. At ages $20-69$ it caused the deaths of $73 \%$ of men and $54 \%$ of women who died of circulatory diseases in England and Wales during 1979-83. These proportions varied in the immigrant groups, being $76 \%$ in men and $56 \%$ in women from the Indian subcontinent and $44 \%$ and $27 \%$ in Caribbean men and women. Deaths from ischaemic heart disease among Indians and Caribbeans constituted $0.8 \%$ and $0.15 \%$ respectively of all such deaths in England and Wales in 1970-2, and these proportions had doubled in 1979-83.

Mortality adjusted for age-Among men aged 20-69 mortality from ischaemic heart disease was highest in Indians (standardised mortality ratio 136) (table I), followed by Irish (114), Polish (114), African (113), and Scottish men (111). Rates were lowest in Caribbean men (45). Mortality among women aged 20-69 showed a similar pattern with the greatest excess seen among women from the Indian subcontinent (standardised mortality ratio 146), followed by the Irish (120) and the Scottish (119). African women did not show an excess, a different pattern to the finding among men. The low levels among women from France, Italy, the United States, South Africa, and the Caribbean and old Commonwealths were consistent with the patterns observed for men from these countries.

Mortality in the young-Excess mortality among men from the Indian subcontinent increased steadily with decreasing age, with standardised mortality ratios of 313 (21 deaths) and 210 (123 deaths) at ages 20-29 and 30-39 respectively. African men also showed a greater excess at young ages, with standardised mortality ratios of 154 and 139 at $30-39$ and $40-49$ respectively. There were insufficient deaths among young women to examine ethnic differences by 10 year age groups. Mortality among the Scottish and the Irish showed a greater excess in both sexes among young adults (ages 20-49) than overall (ages 20-69). Particularly striking was the high rate in Indian men aged 20-49, who showed an excess of $65 \%$ over rates in England and Wales (compared with an excess of 36\% at ages 20-69); in contrast, the excess in young Indian women was lower (standardised mortality ratio 116) than at ages 20-69 (146). Africans showed a similar pattern to Indians, with a higher death rate among young males (139) than at 20-69 (113), whereas young African women did not show a rise. In contrast, the country of birth groups with low mortality at 20-69 showed low ratios also among young adults.

Trends between 1970-2 and 1979-83-In this period mortality in England and Wales from ischaemic heart disease declined by $5 \%$ in men and $1 \%$ in women, with the immigrant groups showing divergent patterns (table I). The greatest percentage declines (of $17-23 \%$ in men and $23-37 \%$ in women) were seen among immigrants from the United States, South Africa, and the old Commonwealth. Sizeable declines occurred also in groups with some of the lowest mortality rates in 1970-2, notably the Caribbeans and French and Italian men.

Some groups with high mortality in 1970-2 showed comparatively little improvement over the decadenamely, the Irish and the Polish. Immigrants from the Indian subcontinent differed from all other groups in that they experienced a rise in mortality (of $6 \%$ in men and $13 \%$ in women) despite having had the highest rates in 1970-2. Among immigrants from the Indian subcontinent, Scotland, Ireland, and Poland mortality from ischaemic heart disease was higher in both sexes in 1979-83 than the levels prevalent nationally a decade earlier.

TABLE I - Mortality from ischaemic heart disease at ages 20-69 by country of birth, 1970-2 and 1979-83

\begin{tabular}{|c|c|c|c|c|c|c|c|c|c|c|}
\hline \multirow[b]{3}{*}{ Country of birth } & \multicolumn{5}{|c|}{ Men } & \multicolumn{5}{|c|}{ Women } \\
\hline & \multicolumn{2}{|c|}{$1970-2$} & \multicolumn{2}{|r|}{ 1979-83 } & \multirow[b]{2}{*}{$\begin{array}{l}\text { \% Change } \\
\text { in SMR }\end{array}$} & \multicolumn{2}{|c|}{$1970-2$} & \multicolumn{2}{|r|}{ 1979-83 } & \multirow[b]{2}{*}{$\begin{array}{c}\text { \% Change } \\
\text { in SMR }\end{array}$} \\
\hline & $\begin{array}{l}\text { No of } \\
\text { deaths }\end{array}$ & $\mathrm{SMR}^{\star}$ & $\begin{array}{l}\text { No of } \\
\text { deaths }\end{array}$ & $\begin{array}{l}\mathrm{SMR}^{\star}(95 \% \\
\text { confidence } \\
\text { interval) }\end{array}$ & & $\begin{array}{l}\text { No of } \\
\text { deaths }\end{array}$ & $\mathrm{SMR}^{\star}$ & $\begin{array}{l}\text { No of } \\
\text { deaths }\end{array}$ & $\begin{array}{l}\mathrm{SMR}^{\star}(95 \% \\
\text { confidence } \\
\text { interval) }\end{array}$ & \\
\hline Scotland & 2996 & 124 & 4959 & $111(108$ to 114$)$ & $-10 \dagger$ & 826 & 124 & 1496 & $119(113$ to 125$)$ & -4 \\
\hline All Ireland & 3113 & 113 & 6225 & 114 (111 to 117 ) & 1 & 950 & 122 & 2023 & $120(115$ to 125$)$ & -2 \\
\hline Indian subcontinent & 1140 & 128 & 3410 & $136(131$ to 141$)$ & 6 & 225 & 129 & 798 & $146(136$ to 156$)$ & 13 \\
\hline Caribbean Commonwealth & 198 & 49 & 669 & $45(42$ to 49$)$ & -8 & 65 & 89 & 214 & $76(66$ to 87$)$ & -15 \\
\hline African Commonwealth & 90 & 116 & 400 & $113(102$ to 125$)$ & -3 & 11 & 78 & 62 & 97 (74 to 124$)$ & 24 \\
\hline Old Commonwealth & 327 & 110 & 584 & $91(84$ to 99$)$ & $-17 \dagger$ & 87 & 94 & 153 & $72(61$ to 84$)$ & -23 \\
\hline West Europe & 335 & 84 & 717 & 77 (71 to 83$)$ & -8 & 160 & 87 & 376 & $81(73$ to 90$)$ & -7 \\
\hline East Europe & 1221 & 111 & 2453 & $112(108$ to 117$)$ & 1 & 182 & 115 & 264 & $110(97$ to 124$)$ & -4 \\
\hline Republic of South Africa & 155 & 117 & 165 & $90(77$ to 105$)$ & $-23 \dagger$ & 63 & 115 & 59 & $73(56$ to 94$)$ & $-37 \dagger$ \\
\hline United States & 201 & 112 & 231 & $86(75$ to 98$)$ & $-23 \dagger$ & 46 & 87 & 40 & $56(40$ to 76$)$ & $-36 \dagger$ \\
\hline All deaths in England and Wales & 134093 & 105 & 207936 & 100 & $-5 \dagger$ & 43234 & 101 & 69248 & 100 & -1 \\
\hline
\end{tabular}




\begin{tabular}{|c|c|c|c|c|c|c|c|c|c|c|}
\hline \multirow[b]{3}{*}{ Country of birth } & \multicolumn{5}{|c|}{ Men } & \multicolumn{5}{|c|}{ Women } \\
\hline & \multicolumn{2}{|c|}{$1970-2$} & \multicolumn{2}{|r|}{$1979-83$} & \multirow[b]{2}{*}{$\begin{array}{l}\text { \% Change } \\
\text { in SMR }\end{array}$} & \multicolumn{2}{|c|}{$1970-2$} & \multicolumn{2}{|r|}{$1979-83$} & \multirow[b]{2}{*}{$\begin{array}{c}\% \text { Change } \\
\text { in SMR }\end{array}$} \\
\hline & $\begin{array}{l}\text { No of } \\
\text { deaths }\end{array}$ & $\mathrm{SMR}^{\star}$ & $\begin{array}{l}\text { No of } \\
\text { deaths }\end{array}$ & $\begin{array}{c}\operatorname{SMR}^{\star}(95 \% \\
\text { confidence } \\
\text { interval })\end{array}$ & & $\begin{array}{l}\text { No of } \\
\text { deaths }\end{array}$ & $\mathrm{SMR}^{\star}$ & $\begin{array}{l}\text { No of } \\
\text { deaths }\end{array}$ & $\begin{array}{c}\mathrm{SMR}^{\star}(95 \% \\
\text { confidence } \\
\text { interval) }\end{array}$ & \\
\hline Scotland & 533 & 128 & 834 & $105(98$ to 112$)$ & $-18 \dagger$ & 425 & 134 & 637 & $110(102$ to 119$)$ & $-18 t$ \\
\hline All Ireland & 756 & 162 & 1175 & $123(116$ to 130$)$ & $-24 \dagger$ & 596 & 158 & 922 & $117 .(110$ to 125$)$ & $-26 \dagger$ \\
\hline Indian subcontinent & 244 & 157 & 645 & $153(141$ to 165$)$ & -3 & 165 & 166 & 347 & $125(112$ to 139$)$ & $-25 t$ \\
\hline Caribbean Commonwealth & 177 & 271 & 419 & $176(160$ to 194$)$ & $-35 t$ & 137 & 307 & 316 & $210(187$ to 234$)$ & $-32 \dagger$ \\
\hline African Commonwealth & 39 & 264 & 103 & 163 (133 to 198$)$ & $-38 \dagger$ & 23 & 253 & 58 & $139(106$ to 180$)$ & $-45 t$ \\
\hline Old Commonwealth & 74 & 153 & 112 & $95(78$ to 114$)$ & $-38 \dagger$ & 63 & 141 & 99 & $101(82$ to 123$)$ & -28 \\
\hline West Europe & 56 & 83 & 97 & $62(50$ to 76$)$ & -25 & 113 & 117 & 163 & $73(62$ to 85$)$ & $-38 \dagger$ \\
\hline East Europe & 237 & 130 & 407 & $105(95$ to 116$)$ & $-19 \dagger$ & 103 & 141 & 117 & $109(90$ to 131$)$ & -23 \\
\hline Republic of South Africa & 33 & 137 & 31 & $93(63$ to 132$)$ & -32 & 39 & 155 & 42 & $112(81$ to 151$)$ & -28 \\
\hline United States & 21 & 68 & 54 & $112(84$ to 146$)$ & $65 t$ & 25 & 97 & 23 & $65(41$ to 98$)$ & -33 \\
\hline All deaths in England and Wales & 31271 & 138 & 37476 & 100 & $-28 t$ & 27428 & 138 & 32037 & 100 & $-28 t$ \\
\hline
\end{tabular}

\section{CEREBROVASCULAR DISEASE}

Patterns in 1979-83-In this period cerebrovascular disease contributed $13 \%$ and $25 \%$ of deaths from circulatory diseases in men and women aged 20-69 in England and Wales. Again, these proportions varied among the immigrant groups, being $28 \%$ in Caribbean men and $40 \%$ in Caribbean women. As with ischaemic heart disease, the proportion of deaths from cerebrovascular causes in England and Wales in Indians and Caribbeans doubled over the preceding decade.

Mortality adjusted for age-Among men, mortality from cerebrovascular disease was highest in Caribbeans (standardised mortality ratio 176) and Africans (163), followed by men from the Indian subcontinent (153) and Ireland (123) (table II). Women showed similar patterns, with the highest rates in Caribbeans (210), Africans (139), and Indians (125). Scottish and Irish women showed a smaller excess. West European immigrants had greatly lowered mortality from cerebrovascular disease.

Mortality in the young-The excess cerebrovascular mortality seen in Caribbean, African, and Indian men was greatest at ages 40-69. Caribbean women also showed an excess over other groups at ages 40-69, with rates double or more than double those in England and Wales overall. The Scots and the Irish showed a greater excess of deaths in both sexes of young adults aged 20-49 than overall at ages 20-69. Women in the different groups generally showed the same patterns as men, except in Indians where ratios at 20-49 were significantly higher in men (standardised mortality ratio 156$)$ and lower in women (81).

Trends between 1970-2 and 1979-83 - In England and Wales mortality from cerebrovascular disease fell by $28 \%$ from $1970-2$ to $1979-83$, a rate of decline shared by most groups (table II). The decline among Caribbean and African immigrants exceeded that observed for England and Wales, but Indian men showed comparatively little improvement, with a fall of only $3 \%$. In Caribbean, African, and Indian men mortality from stroke in 1979-83 exceeded the rate in England and Wales in $1970-2$, a pattern shared also by Caribbean women.

\section{Discussion}

This study is based on the country of birth of the deceased. Ethnic affiliation is not recorded in the decennial census, thus population estimates by ethnic group are not available, making analysis by country of birth the best available proxy for examining population based differences in mortality. Issues relating to country of birth and ethnic groups are dealt with in detail elsewhere. ${ }^{6}$ In summary, for immigrants born in the Indian subcontinent country of birth is considered a reasonable proxy for ethnic origin at younger ages.
African born immigrants, however, include people of African origin and also those of Indian extraction. Immigrants from the old Commonwealth and South Africa are largely of British extraction, as are some German born immigrants.

Analysis by country of birth excludes second generation immigrants born in this country. This affects groups consisting of those who migrated many years ago, especially Russians and Poles, and, to a lesser extent, more recent migrants such as West Indians and those from the Indian subcontinent.

This analysis for 1979-83, the latest period for which national data are available, shows distinct ethnic differences in mortality from ischaemic heart disease. Mortality was highest in those born in the Indian subcontinent, with an excess over the overall rate in England and Wales of $36 \%$ in men and $46 \%$ in women. Indians were the only ethnic group to show an increase in mortality over the preceding decade (of $6 \%$ in men and $13 \%$ in women) despite having had the highest rates in the 1970s.

A study of mortality from coronary heart disease in five London boroughs with substantial Asian populations that covered the same period as this analysis (1979-83) concluded that "mortality from coronary heart disease among Asians in England and Wales has increased by about 25\% since 1970-2." The authors did not make clear how this estimate, considerably higher than mine, was derived, although it seems to be based on a direct comparison of the 1979-83 standardised mortality ratios for coronary heart disease in Asians in the five London boroughs with the 1970-2 standardised mortality ratios for heart disease in Asians in England and Wales. If this was the case then the result is misleading since the two sets of standardised mortality ratios were not standardised on the same base rates. My method, which uses national mortality data for both periods and standardising across time, provides a reliable estimate of the increased mortality from heart disease among Asians in Britain.

High death rates from ischaemic heart disease have previously been reported in England and Wales for immigrants from the Indian subcontinent ${ }^{4}$ despite their considerable cultural, social, and dietary heterogeneity. ${ }^{5}$ The consistent finding of high rates of ischaemic heart disease in expatriates of Indian extraction in many parts of the world has previously been highlighted. ${ }^{\prime}$ An analysis of mortality among Asians, coloured people, and white people in South Africa for a period overlapping with this study (1978-82) confirmed the higher rates of ischaemic heart disease among Asians in that country. ${ }^{8}$

Smoking is recognised as an independent risk factor for ischaemic heart disease,${ }^{9}$ but its prevalence has not always been shown to be greater among those of Indian extraction. ${ }^{10-14}$ High blood pressure is also known to 
have an independent effect on the risk of ischaemic heart disease, ${ }^{9}$ but it too has not always been shown to be of higher prevalence in these communities. ${ }^{115-17}$ Seedat in his review of South African findings contrasts the higher prevalence of hypertension in South African Indians with the estimates for India, ${ }^{18}$ although regional differences in hypertension have been reported from India. ${ }^{19}$ Total serum cholesterol concentration has also been shown to predict ischaemic heart disease." The few surveys conducted among people of Indian extraction have not shown total serum cholesterol concentrations higher than those in the indigenous population, ${ }^{11} 1314$ though in east London the plasma cholesterol concentration in Bangladeshi men under 45 was found to be fairly high." investigating diet have also shown different fat intakes and ratios of polyunsaturated to saturated fats. ${ }^{101314}$ These questions are far from resolved and require further population surveys.

The role of high density lipoprotein cholesterol in ischaemic heart disease has attracted interest since the mid-1970s, ${ }^{2021}$ but recent evidence seems to cast doubt on its protective effect against ischaemic heart disease. ${ }^{922}$ Most surveys conducted among communities from the Indian subcontinent have, however, reported low plasma concentrations of high density lipoprotein cholesterol..$^{11423}$

A study in Trinidad ${ }^{24}$ prompted greater focus on the role of diabetes in the causation of ischaemic heart disease among people of Indian origin. ${ }^{1}$ Diabetes is known to be more common in this ethnic group, a finding reported in several countries ${ }^{25-28}$ and for all the Indian subgroups. ${ }^{511}$ The possible role of insulin in atherosclerosis was hypothesised as far back as 1969.2930 The hypothesis that insulin is linked to the development of atherosclerosis is compatible with the high mortality in Indians from both ischaemic heart disease and stroke. If insulin is a cause of atherosclerosis then the high carbohydrate load traditional among Indians could have a bearing. This could be further accentuated by changes in life style factors such as the lack of regular physical exercise. Physical exercise also has a bearing on glucose and insulin metabolism.

The high mortality from strokes in Indians has not previously been highlighted to the same degree as that from ischaemic heart disease. Mortality from strokes in Indian men was $53 \%$ greater than national levels, whereas the excess in ischaemic heart disease was $36 \%$; in Indian women mortality from stroke was $25 \%$ higher than national levels and that from ischaemic heart disease $46 \%$ higher. These results are supported by findings for the corresponding period in South Africa. ${ }^{31}$

The Asian community is by no means homogeneous, and the studies done so far have not covered extensively the various religious and regional subgroups. There is a need to explore the more conventional risk factors in large representative samples of these communities. In addition, further research has to centre on glucose and insulin metabolism, the diabetic state, and ischaemic heart disease among people of Indian extraction. The 1.3 million people of Indian origin living in Britain provide an unrivalled opportunity to explore the course of these diseases further. While further evidence is awaited, public health measures should be targeted at this population. Apart from recognised risk factors, the importance of regular physical exercise, avoidance of obesity, and moderate carbohydrate load should be considered.

Although Caribbean born immigrants had significantly low death rates from ischaemic heart disease, they had the highest mortality from cerebrovascular disease in both the periods studied, with an excess in $1979-83$ of $76 \%$ in men and $110 \%$ in women. Thus, despite a significant decline in deaths from stroke over the decade, Caribbeans had a higher rate than all groups other than Indians in the early 1980s. These findings are consistent with the results of other studies in Britain. ${ }^{32}$ Hypertension is reported to be the most common chronic disease in the West Indies, ${ }^{3}$ but the raised prevalence in Caribbeans of high blood pressure and of diabetes ${ }^{4}$ is not reflected in mortality from ischaemic heart disease.

Immigrants from the African Commonwealth are predominantly of African or Asian extraction, and in this analysis it was not possible to distinguish between the two. There were excess deaths from ischaemic heart disease and cerebrovascular disease in African men and from cerebrovascular disease in women. Africans also showed excess mortality from diabetes.

Irish and Scottish immigrants showed excess mortality from ischaemic heart disease, reflecting the higher levels prevalent in the respective countries of origin. ${ }^{33}$ Although in Scottish immigrants there was some decline in mortality from this cause over the preceding decade, the Irish were one of the few groups to show no improvement. Both Irish and Scots also showed excess mortality from cerebrovascular disease, with smaller declines over the preceding decade than those noted for west European immigrants, whose mortality levels were lower.

The only Europeans with excess mortality from ischaemic heart disease were Polish immigrants. The low rates in immigrants from west Europe, the United States, and the old Commonwealth, which were in some instances half of those in some other immigrant groups, reflect the lower rates prevalent in the countries of origin..$^{34}$ Mortality from cerebrovascular disease was also low in immigrants from west Europe.

The recent report by the auditor general on coronary heart disease noted that Britain's death rates from coronary heart disease are among the highest in the world and have declined more slowly than in other developed countries. ${ }^{34}$ This study shows that even within England and Wales there were great differences in the degree to which ethnic minorities participated in the national decline observed over the decade. The decline was generally greater in the groups with lower mortality from ischaemic heart disease than in those with higher mortality. Of special concern was the absence of any decline among some ethnic groups (the Indians and the Irish) with high mortality from ischaemic heart disease. Immigrants from the Indian subcontinent were the only group to show an increase in mortality from ischaemic heart disease, despite having the highest levels in the preceding decade.

Mortality in immigrants is affected by many interacting social and cultural factors in addition to the underlying genetic differences and the selection effect of migration. The population dynamics of the various immigrant groups is also dissimilar because duration of residence in Britain varies by country of birth. For example, most Polish and Russian migration occurred very much earlier than migration from the Caribbean, the Indian subcontinent, and Africa; hence Poles and Russians are less likely to reflect the influence of the home country. Nevertheless, it is of concern that ethnic differences in mortality from ischaemic heart disease have widened. For instance, the mortality gradient between Indian and Italian men for ischaemic heart disease increased from 1.88 in the 1970 s to 2.31 in the 1980s. Particularly worrying is the increase in ischaemic heart disease among immigrants of Indian origin; it calls for further research as well as specially targeted public health campaigns.

I thank Dr J Fox, Karen Dunnel, other administrative and clerical staff in the division of medical statistics at the Office of Population Censuses and Surveys, and colleagues at the 
Epidemiology and Public Health Research Unit, University of Surrey. I am specially indebted to Mr L Bulusu and Dr V S Raleigh for their advice.

1 Anonymous. Coronary heart disease in Indians overseas [Editorial]. Lance 1986;: 1307-8.

2 Marmot MG, Rose G. Epidemiology of hypertension. In: Sleight P, Jones JV eds. Scientific foundations of cardiology. London: Heinemann, 1984

3 Grell GAC. Hypertension in the West Indies. Postgrad Med F 1983;59:616-21. Marmot MG, Adelstein AM, Bulusu L. Immigrant mortality in England and Wales 1970-78: causes of death by country of birth. London: HMSO, 1984 Office of Population Censuses and Surveys, studies on medical and population subjects No 47 .

5 Balarajan R, Bulusu L, Adelstein AM, Shukla V. Patterns of mortality among migrants to England and Wales from the Indian subcontinent. $B M \mathcal{J}$ 1984;289:1185-7.

6 Balarajan R, Bulusu L. Mortality among immigrants in England and Wales, 1979-83. In: Mortality and geographv: a review in the mid-1980s, England and Wales. London: Office of Population Censuses and Surveys, 1990. (Series DS No 9 .

7 McKeigue PM, Marmot MG. Mortality from coronary heart disease in Asian communities in London. B.MF 1988;297:903

8 Derry CW, Bourne DE, Sayed AR, et al Variations in mortality of the coloured, white, and Asian population groups in the RSA, 1978-1982. VI. Ischaemic heart disease. S Afr Med f 1987;72:698-700.

9 Shaper AG, Pocock SJ, Walker M, Phillips AN, Whitehead TP, MacFarlan PW. Risk factors for ischaemic heart disease: the prospective phase of the British regional heart study. I Epidemiol Community Health 1985;39: 197-209.

10 Silman A, Loysen E, de Graaf W, Sramek $M$. High dietary fat intake and cigarette smoking as risk factors for ischaemic heart disease in Bangladeshi male immigrants in east London. F Epidemiol Community Health 1985:39: 301-3.

11 McKeigue PM, Marmot MG, Court YDS, Cottier DE, Rahman S, Riemersm RA. Diabetes, hyperinsulinaemia, and coronary risk factors in Bangladeshi in east London. Br Heart f 1988;60:390-6.

12 Balarajan $R$, Yuen $P$. British smoking and drinking habits: variations by country of birth. Community Med 1986;8:237-9.

13 McKeigue PM. Marmot MG, Adelstein AM, et al. Diet and risk factors for coronary heart disease in Asians in northwest London. Lancet 1985; ii: $1086-90$

14 Miller GJ, Kotecha S, Wilkinson WH, et al. Dietary and other characteristic relevant for coronary heart disease in men of Indian, West Indian and European descent in London. Atherosclerosis 1988;70:63-72.

5 De Giovanni JV, Beevers DG, Jackson SHD, et al. The Birmingham blood pressure school study. Postgrad Med 7 1983;59:627-9.

16 Cruickshank JK, Bannan LT, Beevers M, Jackson SHD, Beevers DG, Osbourne VL. Blood pressure in black, white and Asian factory workers in Birmingham. Postgrad Med f 1983;59:622-6.
17 Keil JE, Weinrich MC, Keil BW, Britt RP, Hollis Y. Hvpertension in a population sample of female Punjabi Indians in Southall. $\mathcal{f}$ Epidemiol Community Health 1980;34:45-7.

18 Seedat YK. Race, environment and blood pressure: the South African experience. F Hypertens 1983;1:7-12.

19 Malhotra SL. Studies in arterial pressure in north and south India with special reference to dietary factors in its causation. $\mathcal{F}$ Assoc Physicians India 1971;19:211-24.

20 Miller GJ, Miller NE. Plasma high density lipoprotein concentration and development of ischaemic heart disease. Lancet 1975; ; 16-9.

21 Gordon T, Castelli WP, Hjortland MC, Kannel WB, Dawber TR. High density lipoprotein as a protective factor against coronary heart disease. The Framingham study. Am F Med 1977;62:707-14.

22 Pocock SJ, Shaper AG, Phillips AN, Walker M, Whitehead TP. High density lipoprotein cholesterol is not a major risk factor for ischaemic heart disease in British men. BMf 1986;292:515-9.

23 Miller GJ, Beckles GLA, Alexis SD, Byam NTA, Price SGL. Serum lipoproteins and susceptibility of men of Indian descent to coronary heart disease. The St James survey, Trinidad. Lancet 1982;ii:200-3.

24 Beckles GLA, Miller GJ, Kirkwood BR, Alexis SD, Carson DC, Byam NTA High total and cardiovascular disease mortality in adults of Indian descent in Trinidad, unexplained by major coronary risk factors. Lancet 1986; 1298-301.

25 Zimmet P, Taylor R, Ram P, et al. Prevalence of diabetes and impaired glucose tolerance in the biracial (Melanesian and Indian) population of Fiji: a ruralurban comparison. Am f E pidemiol 1983;118:673-88.

26 Poon-King T, Henry MV, Rampersad F. Prevalence and natural history of diabetes in Trinidad. Lancet 1968; i: 155-60.

27 Omar MAK, Seedat MA, Dyer RB, Rajput MC, Motala AA, Joubert SM. The prevalence of diabetes mellitus in a large group of South African Indians. $S$ Afr Med F 1985;67:924-6.

28 Mather HM, Keen $\mathrm{H}$. The Southall diabetes survey: prevalence of known diabetes in Asians and Europeans. BMF 1985;291:1081-4

29 Stout RW, Vallance-Owen J. Insulin and atheroma. Lancet 1969;i:1078-80.

30 Stout RW. Insulin and atheroma - an update. Lancet 1987;i:1077-9.

31 Disler PB, Epstein L, Buchanan-Lee B, et al. Variations in mortality of the coloured, white and Asian population groups in the RSA, 1978-82. II. Cerebrovascular disease. S Afr Med f 1987;72:408-11.

32 Cruickshank JK, Beevers DG, Osbourne VL, Haynes RA, Corlett JCR, Selby S. Heart attack, stroke, diabetes, and hypertension in West Indians, Asians, and whites in Birmingham, England. BMF 1980;281:1108.

33 Faculty of Community Medicine of the Royal Colleges of Physicians of the United Kingdom. Coronary heart disease. I. Epidemiology. London: RCP 1988. (Guidelines for health promotion number 14. Produced by the Working Group on Coronary Heart Disease of the Committee on Health Promotion.

34 National Audit Office. National Health Service: coronary heart disease. Report by the comptroller and auditor general. London: HMSO, 1989.

\title{
Bupivacaine versus bupivacaine plus fentanyl for epidural analgesia: effect on maternal satisfaction
}

\author{
J D Murphy, K Henderson, M I Bowden, M Lewis, G M Cooper
}

\section{Department of}

Anaesthetics, Birmingham

Maternity Hospital,

Queen Elizabeth Medical

Centre, Birmingham

B15 2TG

J D Murphy, FCANAES, senior

registrar

K Henderson, MRCPI,

registrar

M I Bowden, FCANAES,

registrar

M Lewis, FCANAES,

consultant

G M Cooper, FCANAES, senior

lecturer

\section{Correspondence to: \\ Dr J D Murphy,}

Department of Anaesthetics,

Walsgrave Hospital,

Coventry CV2 2DX.

BMF 1991:302:564-7

\section{Abstract}

Objective-To compare a combination of epidural fentanyl and bupivacaine with bupivacaine alone for epidural analgesia in labour and to evaluate factors in addition to analgesia that may influence maternal satisfaction.

Design-A prospective randomised pilot study.

Setting-Birmingham Maternity Hospital.

Subjects -85 primiparous women who requested epidural analgesia in labour and their babies.

Interventions - Group 1 mothers were treated with bupivacaine conventionally, group 2 mothers with bupivacaine and fentanyl in a more complex way designed to provide satisfactory analgesia but with less troublesome side effects.

Main outcome measures-Overall maternal satisfaction, maternal perception of epidural analgesia and its side effects, and aspects of mothers' psychological states during labour, quantified using $100 \mathrm{~mm}$ visual linear analogue scales; the frequency of normal and operative deliveries; and measurements of neonatal wellbeing.

Results-Satisfaction was higher in group 2 mothers (median group difference $+3 \mathrm{~mm}, 95 \%$ confidence interval +1 to $+5, p=0.012)$ : this was associated with more normal deliveries (difference between proportions $0 \cdot 23,95 \%$ confidence interval +0.03 to +0.42 ); greater self control (median group difference $-7 \mathrm{~mm},-17$ to $-2, p=0.003)$; and reduced unpleasantness of motor blockade $(-10 \mathrm{~mm}$, -19 to $-5, \mathrm{p}<0.001)$, sensory blockade $(-5 \mathrm{~mm}$, -11 to $-2, p=0.002)$ and shivering $(-5 \mathrm{~mm}$, -18 to $0, p=0.046)$ at the expense of mild itching $(0 \mathrm{~mm}, 0$ to $0, p<0.001)$. Group 1 mothers found restricted movements more unpleasant $(-1 \mathrm{~mm}$, -11 to $0, p=0.006)$ and were more sleepy $(-4 \mathrm{~mm}$, -20 to $0, p=0.032$ ). The addition of fentanyl to bupivacaine reduced the requirement for local anaesthetic $(-33 \mathrm{mg},-55$ to $-15, \mathrm{p}<0.001)$ without compromising analgesia. No adverse effects in neonates were attributed to the use of fentanyl.

Conclusions-The already high maternal satisfaction from conventional epidural analgesia can be improved; epidural fentanyl may be combined with bupivacaine to reduce operative deliveries and confer other advantages that may increase maternal satisfaction. Further investigations should be performed to determine the exact mechanisms of these findings and, in particular, to develop a safe method of delivering such analgesia to women.

\section{Introduction}

The quality of epidural analgesia in labour has often been assessed by a simple statement that describes how well the mother was satisfied with the pain relief from 